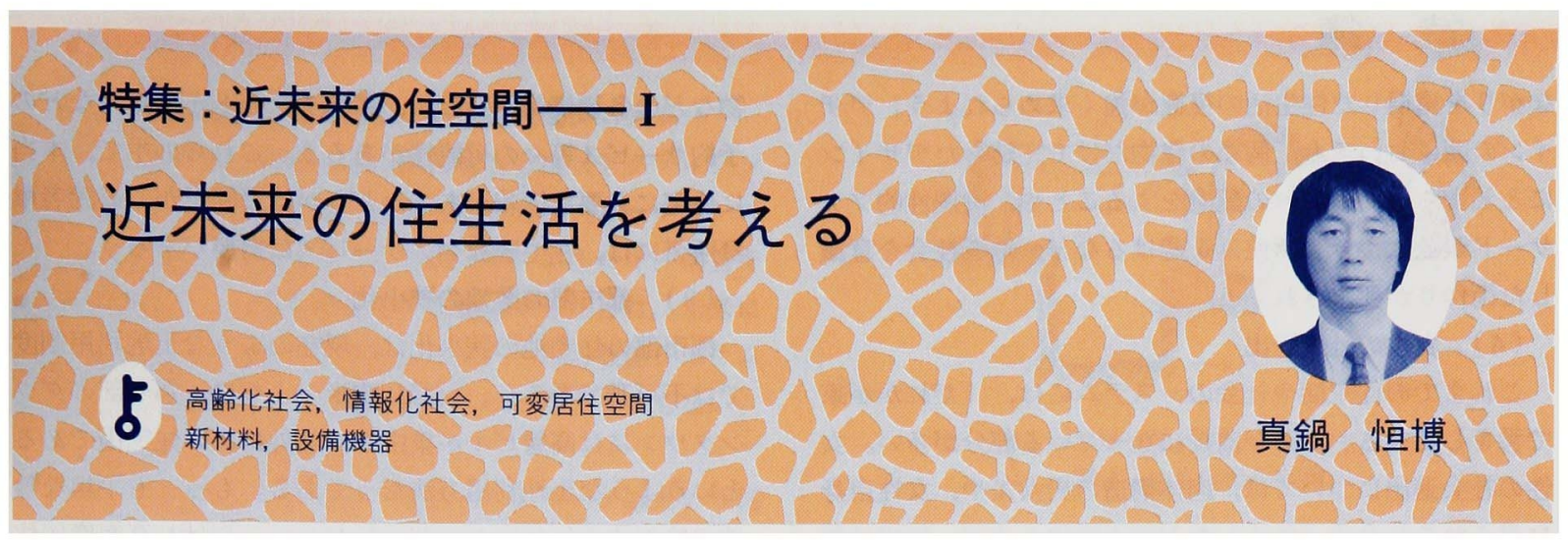

\section{1. 住宅設計と未来予測}

ある開発研究テーマが世の中で一斉に取りあげられて, 一種のブームとなることがある。住宅に関連するこの種の 流行テーマとしては, 例えば十数年前の第一次省エネルギ ーブームがあった。断熱性に対する認識は現在でも不十分 であるとする見解はあるが, それまで熱負荷計算の対象と してはまともに取り上げられなかった戸建住宅において も，断熱性の向上や太陽エネルギー利用の促進などが真剣 に考えられるようになったことは, 大きな進歩であった。 人類の文明は無限に成長・発展するという前提への疑問も 呈され，現代文明自体の否定につながる議論もあった。

省エネルギーブームが去ったあとは, 現代文明否定の風 潮などどこかへ行ってしまい, 再び技術至上・高度成長時 代を迎えた。住宅においても，ホームオートメーションな ぞの情報機器の導入など「高度成長, 技術力信頼」型テー マが脚光を浴びた。新材料・新技術の発展がますます期待 されるようになり，建築の分野にもこうした新技術を応用 して次世紀に向かった技術開発を目指そうという動きが各 所で見られた。集合住宅にも，戸建住宅にも，いろいろな 機関（要するに建設省と通産省が並行して）や住宅メーカ によって, 近未来の住生活をイメージした住宅建築の提案 がなされた。当時は「21世紀」が合言葉であった。

また，人類がこれまでに経験しなかった空前の高齢者社 会を迎え, 高齢者・身障者対応住宅が恰好の研究・開発・ 設計のテーマとして取り上げられるようになり, 各所でさ まざまな高齢者対応型住宅の試作・提案があった。これは 今でもさかんに取り上げられているテーマである。

その後はご存じのとおり, 環境問題が一世を風靡してい

まなべ・つねひろ 1968 年東京大学工学部建築学科卒業, 1973 年同大学院博士課程修了。現在, 東京理科大学工学部建 築学科教授。工学博士。専攻分野：建築計画, 建築構法計画, 住宅設備, 構法史, 省エネルギー。最近の著書：「設備から考 える住宅の設計」「住宅部品を上手に使う」「建築単位の事典」
る。前回の省エネルギーブームが「石油枯渇」を論拠とし ていたのに対して, 今回は環境污染防止・ $\mathrm{CO}_{2}$ 排出削減を 目的として再び省エネルギーブームが起こっている。こう して，いろいろなテーマがブームとして去来する。

一頃,「未来住宅」が一種のブームとなったことがあ る。具体的な単一の目標を失ない, それまでに出てきた上 記のいくつかのテーマを統合して, 今後予測される社会の 変化に対応していこうというものであった。これについて も, やはりいくつもの機関によって未来住宅の研究が行わ れ, いずれの研究においてもほぼ共通の見解が得られてい た。この時代にさかんに研究され議論された各種の「未来 予測」や，それに対応して適用されるべき技術，必要とさ れる技術に関する検討は, ブームが去ったからといって無 視されるべきものではない。当時の検討内容を参考に, 現 時点における「近未来の住生活」について検討してみる。

\section{2. 社会動向予測と住生活の未来像}

近末来の社会の動向予測と, それに対応して発生する住 宅への要求項目については, 以下の項目があげられよう。

\section{（1）多様化, 個性化}

都市部に多い単身世帯や, 同性同居などは, 現在でもそ うそう珍しくない存在となったが，これまでの住宅の存在 の前提となっていた「家庭」自体の多様化が予測される。 「夫婦に子供が 1 ～ 2 人」という平均的家庭像にとらわれな い, さまざまなパターンの「家庭」の発生に関連して, 住 宅のデザインやプランニングも多様化するであろう。

\section{(2) 国際化社会}

外国人の姿を見る機会がずいぶん増えた。日本人の間で も「外国風」のライフスタイルが徐々に増えている。これ に対応して, 例えばホームパーティを開く機会が増えるな ど，住宅のプランニングにも影響があろう。

\section{(3) 地域社会との連係}

周辺社会との交涉もなく, 隣人との付き合いもないよう な居住スタイルの蔓延が, 都市部では憂慮される。予測と いうよりはむしろ期待であろうが，今後は地域社会へのつ 
ながりを重視した住生活の復権が強く求められよう。デザ インの面においても，個々の建物だけで完結したデザイン にとどまらず，街並への配慮をすることや，没個性的ファ サードが並ぶような街並みを避けるなど, 地域社会を意識 した街作りが要求されよう。

（4）女性の社会進出

これまでの住生活や社会のシステムには，「だれかが家 で番をしている」ことが前提になっている部分が多い。女 性の社会進出については, 肉体構造の男女差や，女性自身 に見られる社会的「甘え」など賛否両論あるが，現実は着 実に進みつつある。これによって家には常にだれかがいる という前提がなくなる。子育てや親子の接し方などがどう あるべきか, どうなっていくかについては，実際のところ よくわからないのだが，少なくとも住宅の設計おける「不 在時への対応」という問題は無視できない。

\section{(5) 高齢化社会}

高齢化社会については，現在生き残つている高齢者が若 いころに自然で健康な環境に育ったからであり, 将来的に はこんなに長生きする者が増えることはない, という穿っ た見方もあるが，高齢化・長寿命化は間違いなく進みつつ ある。これに対応して, 加齢や病気・怪我によって生ずる 機能低下をバックアップする各種の機能を持つ住宅, すな わち $\mathrm{HC}$ (ハンディキャップト) 者に対応する住宅に関す る研究開発が行われている。

\section{（6）生活水準の向上}

エネルギー消費や環境破壊をこれ以上増やさず，むしろ 積極的に削減しつつ, 生活水準の向上を図ることは, 以前 の省エネルギー時代からの目標であったが, 石油ショック が去ると, もとの木阿弥になってしまった。環境問題から 再び省エネルギーが叫ばれているが, $\mathrm{CO}_{2}$ と地球温暖化の 関係など，まだ科学的に解明されていない現象が行政上の スローガンになっていることは，ちょっと気になる。

\section{（7）高度情報化社会}

住宅の高度情報化については，メーカの側からは新しい 市場開拓として興味あるテーマであろう。コンピュータ利 用の設備機器・家電機器は見えないところでどんどん普及 しているものの, 情報機器という面ではあまり事態は進ん ではいない。家庭内に仕事を持込む以外には，住宅にはも ともとわざわざ余計なコストをかけてまで処理しなければ ならないほど情報量は多くないという考えもあろう。

\section{（8）社会サービスの充実}

住宅にも情報ネットワークが整備されるためには，ただ ハードが完備するだけでなく，各種の社会的情報通信サー ビスなどのソフト面の充実が前提となる。その内容として は, 在宅診療などの医療サービス, 在宅買物サービス, 催
物などの各種情報サービス，各種チケット・乗車券などの 予約サービス等々の可能性があろう。これらの中で, 本当 に住宅に必要な情報があるかどうかは疑問だが, 高齢者単 身所帯には, 在宅医療ケアサービスは需要があろう。

\section{（9）都市部の敷地の狭小化}

都市部の住宅地の狭小化は, 現在のような土地利用制度 では不可避であろう。ただし欧米のように，都心部のダウ ンタウンには高層ビルが集中し, 郊外は広い住宅街である というような土地利用方法だってある。もっとも平坦な敷 地の絶対的不足はいかんともしがたい。やはり高密度居住 を追求することは未来でも主要なテーマであろう。

(10) 環境污染の深刻化

これは都市部の住宅ではたしかに重大な問題である。都 心部の夜間人口減少と通勤ラッシュを解消するために, 都 心部にも住宅を供給すべきであるという考えはすでに実行 されているが, 都心の污ない空気を吸いたくないという要 求も強い。それに, 都心の高額な物件は, 「普通の」生活 をする人にはなかなか取得できない。

(11) 自然の希少化

上記のように, 郊外の田園地帯の豊かな自然に対する要 求は根強い。都心に住居を作るならば, やはりこうした自 然への要求を満たす方法を考えておく必要がある。

\section{（12）資源の枯渴}

石油ショックが作為的な原油価格吊り揚げであり, 当面 石油の枯渴の心配はないとしても, 有限の物はいつかはな くなるという事実に変わりはない。

\section{（13）耐久性・耐用性の希求}

我が国の現在の住宅の耐用年数は 20 年ぐらいと言われ ている。部分的な劣化や, 周囲の条件の変化など, 物理的 な耐久性の限度に達する前に取り壊されている。しかしこ うした「使い捨て」住宅には愛着も湧かず，日常的な性能 にも限度がある。だいいち資源利用上からも無駄が多い。 十分な広さと耐久性のあるしっかりした建物を，長期にわ たって「愛用」するように，方向転換する必要がある。

\section{3. 住生活の未来像と要素技術}

上記のような社会情勢の変化の予測に対応して，住宅設 計上ではいくつかの要素的な技術, 手法, あるいは設計上 の命題とでも言うべきものがあげられる。以下にその主な ものをあげる。

（1）自然エネルギー利用

省エネルギーや環境保全の目的で, 自然エネルギー利用 が必要であることは言うまでもない。現時点でコスト的に 成立しなくても, 将来を見越した技術開発は不可欠であ る。(図 1)。 
（2）環境制御設備・部位，高性能設備システム

自然エネルギー利用には, 設備的な方法（アクティブシ ステム) と，建築設計上の工夫による方法（パッシブシス テム）がある。両者をうまく併用して，エネルギー消費を 増やすことなく，室内環境条件を確保することは，未来に おいても重要な課題となろう。また,一般の設備システム の機能・性能の向上が必要であることは言うまでもない。

\section{(3) 躯体用新材料}

これまでの木造・鉄骨造・鉄筋コンクリート造という区 分にとらわれない, 新しい発想の躯体材料が現われてもよ い。ただし，建築用の材料には，ある一定のスケールの空 間を覆うための「量」が必要である。リサイクルを考慮し た新しい材料・構法の出現が期待される(図 2)。

\section{(4) 可变住空間}

住宅の性能確保の基本は広さである。十分な広さのスぺ ース（床面積，階高とも）と，十分に耐久性のある躯体が あれば，住宅の寿命を延ばすことは困難ではない。間仕 切・内装・設備機器のほか, 外周壁に対しても, 可変性を 与えることで，条件の変化に対応した住宅を実現すること ができる(図 1)。

（5）増改築システム, 増改築 DIY 支援システム

前述の可変性の一環として, 建物の増改築がある。小規 模な増改築・リフォームには，ユーザ自身によるDIY（ド ウーイットユアセルフ）も可能であろう。このためには 施工が容易な「キット」システムなど，ハード面・ソフト 面の充実が期待される。（図 4)

（6）地下室キット，掘削技術

狭小な都心部でのスペース確保の方法には屋根裏空間と 床下空間（地下室）があり，現在も普及しつつある。地下 室は掘削・施工にコストがかかるため, 寒冷地以外ではあ まり普及していない。地下室工事が安価・容易にできる方法 が開発されれば，さらに普及することが期待される (図2)。

\section{（7）宅内情報システム}

住宅にもさまざまな情報機器を取り入れようという動き があるが，実際にはあまり普及してはいない。パソコンや ファクシミリが住宅にあるというのは，多くの場合仕事を 家庭に持ち込んでいるに過ぎない。出先から自宅の風呂釜
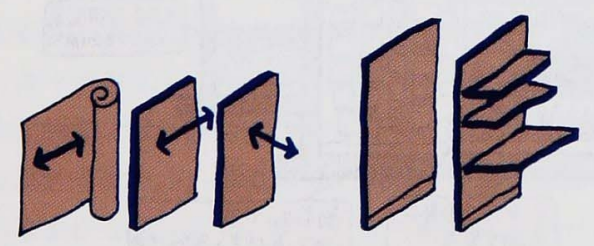

要求の変化に対応して長期的・短期的に変化し得る内外装・間仕切等 図 1 可変住空間

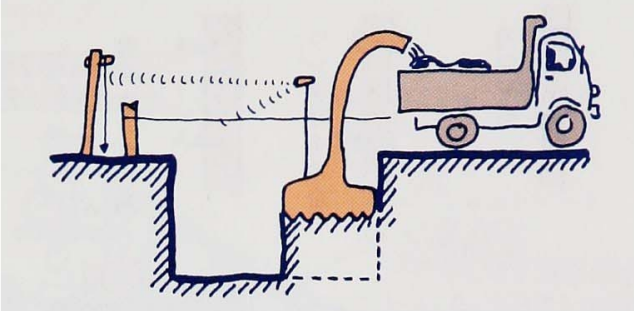

施工が容易な掘削技術と地下室キット

図 2 地下室掘削技術

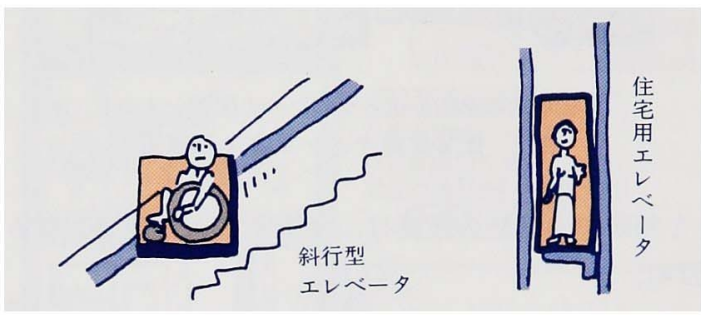

エレベータなどのほか, 身障者用リフトなどが実用化されている 図 3 宅内般送設備

に点火することは技術的には可能だが，大容量の給湯設備 があれば何の問題もない。住宅などというものは，もとも と原始的なもので十分であり, 高度な情報機器を必要とす るほどの情報量がないのかも知れない。

\section{（8）宅内エレベータ等搬送機器}

高齢化社会に対応する技術・部品の代表例として，住宅 用エレベータがある。個人の住宅に設置可能な価格のエレ ベーターが既に発売されており，車椅子対応の必要な住宅 では貴重な存在である。ただし，高齢者・身障者といって もさまざまな「障害」の内容があり，一律の対応などはあ りえない(図3)。

（9）設備配管・配線のフレキシビリティ・互換性

住宅設計にはフレキシビリティが必要である。フレキシ ビリティには, 設計上の自由度確保（フレキシビリティ・ イン・プランニング） と, 時間的変化への対応（フレキシ ビリティ・イン・タイム) がある。いずれに対しても，配 管・配線のフレキシビリティ，すなわち着脱・互換・交換 などが可能なシステムが要求される。

\section{（10）高耐久性設備配管}

設備（機器・配管）は建築躯体に比べて寿命（耐久年 数・耐用年数）が短い。耐久性（物理的な寿命）に対して は高耐久設備が，また耐用性（用途変更・陳腐化など社会 的な寿命）に対しては交換可能な構法が必要とされる。

(11） 診断・メンテナンス技術

設備配管や，建築躯体の劣化の程度を適格に診断するこ とは，適切なメンテナンスの必須条件である。躯体や配管 の内部を非破壊的に診断し，必要なメンテナンス行為の選 


\section{特 集}

\begin{tabular}{|l|l|l} 
透 \\
明 \\
配 \\
管
\end{tabular}

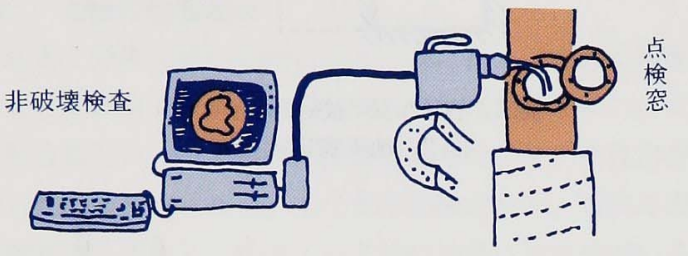

非破壊的な診断方法とそのための配管システム

図 4 配管診断・メンテナンス技術

定を判断するための技術は，今後ますます重要となろう (図 4)。

\section{4. 近未来の戸建住宅イメージ}

一インテリジェント型

上記の各技術は，条件に応じていろいろに組み合わされ る可能性がある。その一つとして, さまざまな新しい技術 を取り入れたインテリジェント型を想定して図示してみよ う。オフィスビルでは高度情報化対応・自動制御などの機
能を持つものを「インテリジェントビル」と言われる。住 宅にもインテリジェント住宅があってよい。この考え方 は，ひところ「スマートハウス」などの名称で欧米でも提 案されていたが，今はどうなったか。上記のように，住宅 にはそもそもそんな情報量がないのかも知れない（図5)。

\section{5. 近未来の戸建住宅イメージ・フルケア型}

高齢者対応，身障者対応，いわゆる「 $\mathrm{HC}$ 者」(ハンデ イキャップト者）対応は，やはり不可避のテーマであろ う。建築の研究界でも, 特に女性研究者には恰好のテーマ と見えて，研究者は多い。学生の卒業設計の傾向を見る と，女子学生の好んで取り上げるテーマでもある(図6)。

\section{6. 近未来の住宅供給と炎の支援システム}

住宅を選ぶ行為は住生活上とても大切なことだが，その 中でも住宅を取得するという行為は，ユーザにとっては一 生にそう何回もあることではなく，わからないことだらけ である。住宅の供給者にとっては，ただハードを建設する だけではなく，それに関するさまざまなソフトの支援があ って，はじめて住宅取得から最終処分まで一貫したサービ スを供給することが可能になる。住宅供給者側には，今後 こうしたトータルな一貫サービスが要求されよう。住宅供

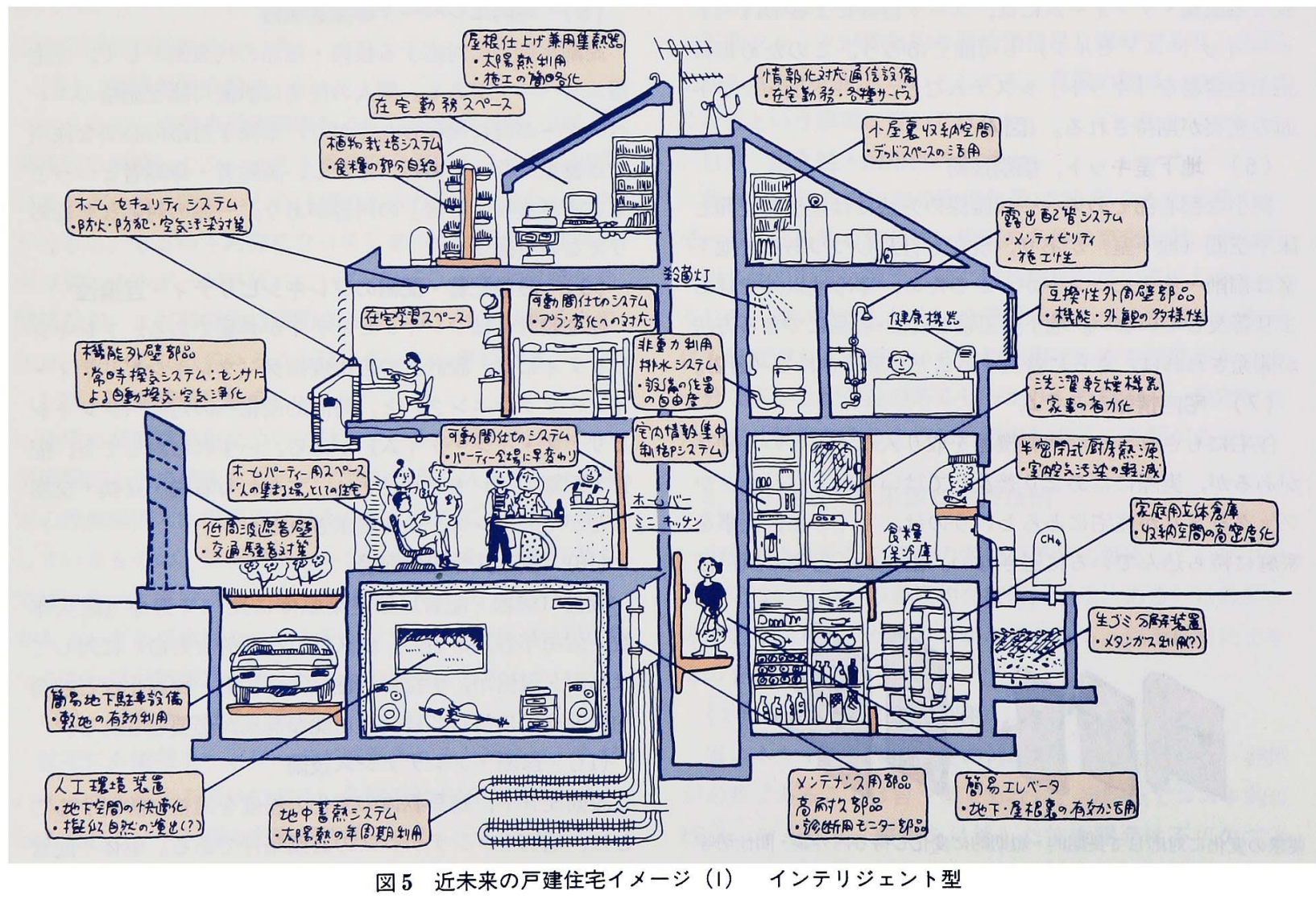




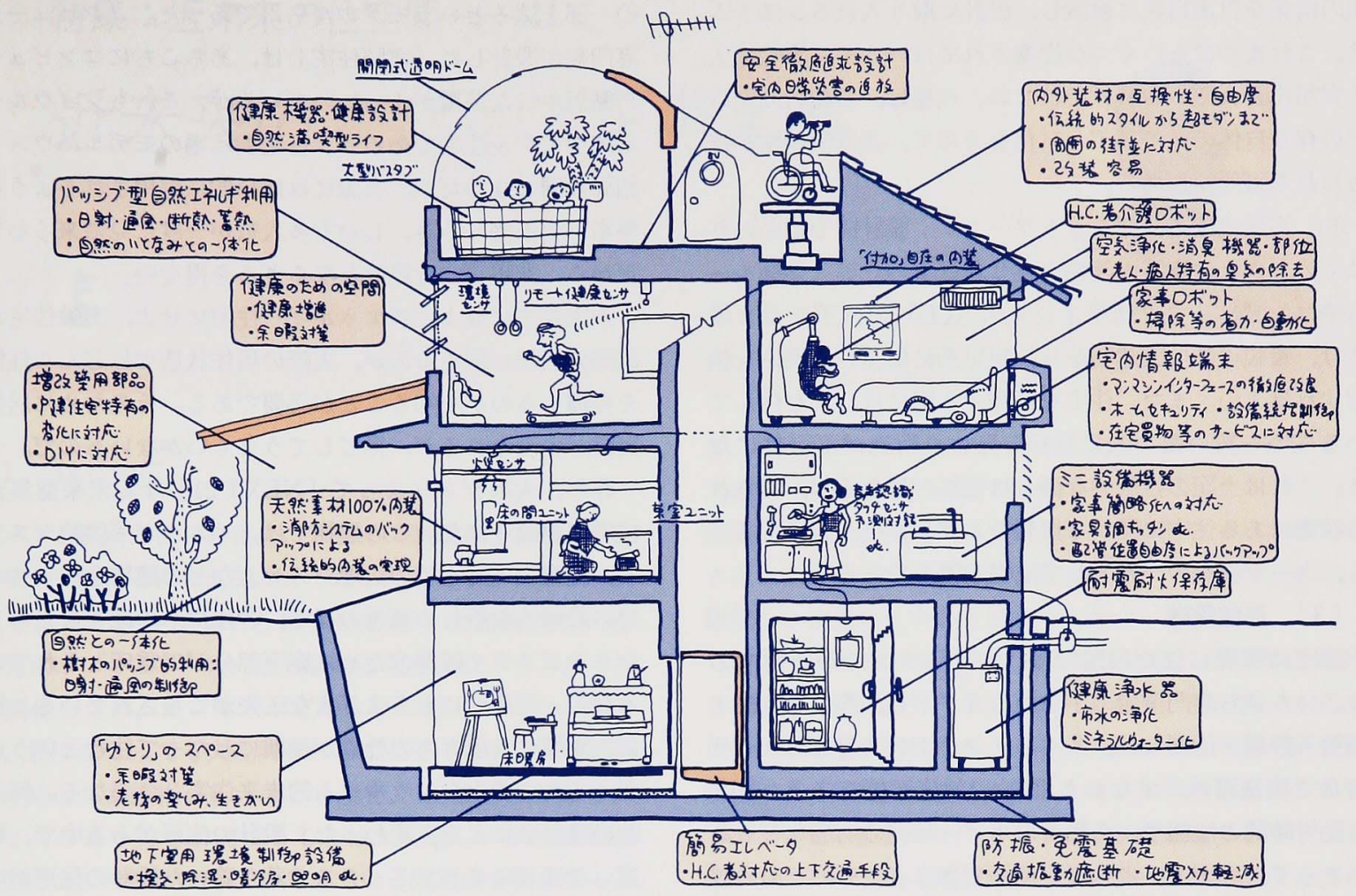

図 6 近未来の戸建住宅イメージ（2）フルケア型

給に関連して必要となると思われるサービスを, 時系列を 追って順に見てみる。

\section{（1）住宅取得準備段階}

住宅の取得に関するさまさまな知識に関する，ユーザ教 育システムの充実が必要である。資金計画, 税務処理, 物 件情報, 売買仲介, コーポラティブハウス結成仲介, 建築 協定締結斡旋等々の内容がある。

\section{（2）設計段階}

住宅, 特に戸建住宅の設計においては, 設計内容へのユ ーザの意志の反映や，ユーザによる完成状態の建物のイメ ージ把握, 簡単に言えば設計内容の納得のためには, 設計 段階へのユーザの参加が望ましいという考え方がある。し かし専門家ではないユーザに対しては, ユーザが容易に参 加し得るための設計支援システムが必要である。さまざま な形のユーザ参加があり得るが, 例えば以下のようなもの が考えられ，また一部ですでに実用段階に達している。

(1) ユーザ参加 CAD システム： ユーザに理解しやす い三次元画像で設計内容を表示し, リアルタイムで修正し ながら設計を進める。最近では, 両眼立体視で実際の住空 間にいるようなシミュレーションを可能にするバーチャル リアリティが試みられている。実際には計算機コストや操 作手間などの関係から，「見せ物」の段階のようである。
コンピュータ技術の発達速度は我々の想像を絶するので, まもなくもつと身近なものになるかもしれない。

(2) 立体 $\mathrm{CAD}$ 入力ツール：図面から実際の空間を想 像するのは苦手であるという素人ユーザには, 模型で示す ことがよく行われる。これを小型カメラで実際にその建物 内部にいるようなアングルから見せることも，かなり前か ら実現されている。そこで, 模型の部品を並べるとそのま まCAD のデータに変換できるような入力ツールもあって よい。しかしこの考え方は, 手書き入力ワープロと同種の ものであり, キーボード入力に慣れればかえって煩わしい のと同様, 図面に慣れてしまえば無駄かも知れない。あく まで素人ユーザ向けであろう。

(3) 実大体験ルーム：同様に, 縮尺図面から実際の空 間のスケールを把握することは素人ユーザには難しい。実 際の部屋の大きさを実大模型で表わし, さらに壁・天井・ 床のほか, 空外の景色まで, 人工映像技術で再現すること も, 原理的には不可能ではない。もっとも, 後述の実物を 見せる方式のほうがさらに直接的であるが。

(4) 建材・部品・機器情報システム：建物を造るため には, さまざまな建材・部品・機器が使われていて, 現在 では建物のほとんどの部分が工業生産化された部品で構成 されていると言っても過言ではない。これらの無数の部品 
類の情報を自由自在に検索し，設計に取り入れるシステム は, これまでにもいくつか提案されてはいるが, 実際に広 く実用化されているわけではない。今後は, 各種のカタロ グの存在自体の電子メディア化を含めて, 高度情報化が進 められる可能性がある。

(5) 実居住住宅公開ネットワーク：設計図ではわかり にくいときには実際の建物を見せればよい。実大体験ルー ムやコンピュータグラフィックス (CG) では不十分な場 合は, 参観可能な実建物から, 想定例に似ている実例を検 索すればよい。また, 住宅を転売する際には, まだ住んで いる住宅を買いたい人に見せるという行為が不可欠にな る。これは上記の技術的な面とは性格が異なるが, 見られ る状態にある住宅に関する情報をネットワーク化すること も，ユーザ支援の一環として成立し得るであろう。

\section{（3）居住段階}

住宅に実際に住む段階では, メンテナンスが重要であ る。いちいち専門業者の手を煩わさずとも，簡単な点検・ 調整・修理・清掃など, 多くのメンテナンス行為はユーザ 自身で実施可能，すなわち DIY で対応可能である。DIY は勤労時間の短縮や, 高齢者のホビー時間の増加などもあ いまって, 今後大いに発展が期待できよう。そのための技 術・知識・工具・材料などの供給支援サービスも, 良好な 社会資本ストックを維持するために不可欠であろう。

さらに, 居住行為自体に対する知識・技術に関する支援 も, 実際には必要である。すなわち, 上手な物の置き方, 設備機器の調整方法, 可変部分の動かしかた等々, 住まい 方全般に対する諸般の技術・知識は, 今や日常生活で親か ら子へと伝承されるだけでは不十分になっている。

（4）増改築・リフォーム段階

居住者側の要求の変化に対応して, 間取り・内外装・設 備等の変更などのリフォームや, 増改築が必要になる。こ れに関しても, やはり同様にユーザ支援システムの充実が 期待される。DIY 方式の導入も大いに可能性があろう。

\section{（5）処分段階}

住宅に住めなくなった場合, 一時的あるいは長期的な賃 貸, 売却, 贈与・相続などの処分が必要になる。これもュ ーザにとってはそうそう経験を積むこともできず，不安が いつぱいの行為である。特に人の死が絡む事態や住み変え の同時売買など，時間的な余裕がないことも少なくない。 上記同様のソフト面の支援システムの充実が期待される。

\section{7. 未来住宅の試作例}

こうした未来を想定した住宅はいくつか試作されたが, 実際に人が住んでいる例はきわめて稀である。全電化住宅 の試作にかかわったこともあるが, 住宅展示場に集合住宅
の一部を造るというモデルルームであった。コンピュータ 専門家が設計した「電脳住宅」は, あちこちにコンピュー 夕制御された装置がくっついているが,これもショウルー ム的なモデル住宅であろう。住宅展示場のモデルハウスも 結局は同じなのだが，実際には部分的に採用されるような 要素を全部盛り込み, しかも多人数が一度に見に来るわけ だから，非現実的な設計とならざるを得ない。

末来住宅にせよ, 省エネルギー住宅にせよ, 実験住宅が 実際の居住に耐えるのか, 実際の居住状態ではどんな性能 を発揮するのかを知ることが必要である。そのために居住 実験が企画されるが，得てしてうまくいかないものだ。

昨年, 大阪ガスによって「NEXT21」なる未来型集合 住宅が建設された。この建物では，エネルギー供給システ 么, 廃棄物・污水等の処理システムなどの建物全体レベル での設備的な新しい試みのほか, 各住戸への配管などのフ レキシビリティ確保のために廊下部分が二重床とされてい るなど, 建築的にもさまざまな工夫がこらされている。特 に, 実際に大阪ガスの社員が長期にわたって住むという点 が,これまでのショウルーム的末来住宅とは異なる。何人 かの建築家による「変わった」設計の住戸がある中で, 場 違いなほどにオーソドックスで落ち着いた設計の住戸がい くつかある。これは実際にそこに住む人の要求を入れて設 計された現実的な住居であり，これらの住戸には外見上の 「未来性」はほとんど見られない。やはり「未来性」を強 調すると，非現実的なショウルームになってしまうよう だ。

\section{8. これからの住生活像}

住宅の使い方，手入れのしかたは，ことさら教育するま でもなく, 日常の行為の中で, あるいは親から子へのしつ けとして伝承されてきた。しかし住宅の構法は過去の物と は大きく様変わりし，今までにはなかった新しい機能や機 器類が住宅内に入り込んでいる。それに対応するには, 積 極的な教育・啓蒙行為が必要である。今後は, ハード技術 の開発だけでなく、むしろそれを成立させバックアップす るためのソフト面の充実が，より一層重要なものとなろう。

人類が初めて月面に到達したころは「人類は宇宙へ行け るようになった」と思った。しかし今にして思うと，「人 類は過去に月に行けたことがある」と言う方が正しい。技 術の無限の発展を過信する時代は終った。豊かで安全な生 活を送るために必要なものは, ハードな技術だけではな い。近末来の住生活像の要点としては, 過去にあった SF 的な末来像ではなく, 我々が失いつつある本質的な「何 か」を取り戻すことに重点が置かれる心゙きであろう。

(平成 6 年 6 月 16 日受付) 